\title{
Corporate Corruption in Megaprojects: The Case of an Institutionalization of a Construction Cartel
}

$\underline{\text { Authors }}$

Armando Castro, UCL, a.castro@ucl.ac.uk 


\title{
Corporate Corruption in Megaprojects: The Case of an Institutionalization of a
}

\section{Construction Cartel}

\begin{abstract}
Although managers might deal with or be aware of corrupt practices in their professional settings, how corruption is maintained is still an under-researched in management. In this paper, I analyze the corrupt side of management enacted by a group of construction companies' suppliers of the oil and gas company Petrobras involved in a portfolio of megaprojects from 2002 to 2014 in Brazil. I use a non-traditional dataset, verifiable court decisions, and plea agreements, and analyze the set of rules created by a corrupt cartel. I find that for a cartel to enact corruption in a portfolio of megaprojects for several years, a set of institutionalized rules of engagement must exist among once "rival" firms. However, these governance practices are based on trust since contractual agreements can't be drafted or enforced. Then, I develop a model that explains the maintenance of long-term corrupt relationships. Finally, I contribute to the theory development of institutional work by explaining the institutionalization of corruption and identifying how institutional work is used for the maintenance of corrupt cartels practices.
\end{abstract}

Keywords: Corporate Corruption, Corporate Social Irresponsibility and Misconduct Qualitative 
Corruption is a grand societal challenge that erodes trust in industries (e.g., construction company cartels in the Netherlands, Dorée, 2004), affects the governance of companies (e.g., Siemens Corruption scandal, Schembera \& Scherer, 2017), and leads to overall financial losses in megaprojects (Locatelli et al., 2017). Therefore, management scholars need to better understand how governance mechanisms and trust can be used to reduce corruption in megaprojects' teams and network partners. However, though project managers might deal with or be aware of corrupt practices in their professional settings, how companies sustain corrupt practices is still an under-researched in management (Castro, Ansari, 2017).

Megaprojects are intrinsically complex (Giezen, 2012), and one way to analyze their complexity is through institutional theory (Biesenthal et al., 2018). One way to try to understand institutionalization is to use institutional work, which project-management scholars have only recently started using (e.g., Lieftink et al., 2019; Van den Ende \& Van Marrewijk, 2019). Due to the nature and complexity of megaprojects, a limited number of companies in the world can both deliver the key technical aspects and coordinate a portfolio of megaprojects simultaneously. These companies face several risks and uncertainties (Bechky, 2006) and to minimize risk and increase profits, they may be tempted to maximize profits by coordinating the prices of projects within the megaprojects or limit the competition among themselves by creating a cartel.

This research is based on several megaprojects of Petrobras, a Brazilian oil and gas multinational, that is one of the largest companies in the world. For over a decade (2002-2014), in the commodity boom of oil, it simultaneously launched a series of tenders for ambitious megaprojects worth hundreds of billion dollars. I explore an extremely complex and successful corrupt cartel of construction companies working on the megaprojects of Petrobras in Brazil until 2014. To understand how this cartel supplying Petrobras created its governance, I draw on data from the highly publicized investigations in Brazil and the US, the Lava Jato (Car 
Wash). The Car Wash investigation is an ongoing investigation into the payment of between $\$ 2$ billion and $\$ 4$ billion in bribes by construction companies to Petrobras executives and their political patrons in this portfolio of the company's megaprojects. The criminal investigation that took place in Brazil has so far led to more than 953 arrest warrants, 188 condemnations, and 163 plea agreements of executives, lobbyists, and politicians. The Brazilian prosecution team and the US Department of Justice have made the legal documentation of the investigations publicly available. These documents contain the details of several plea agreements of the executives of construction companies involved in megaprojects of Petrobras. This rich amount of data offers the chance to analyze in-depth the corrupt network and view some of the corrupt governance mechanisms that are not often publicized in these contexts. Additionally, these documents were triangulated with the financial and project statements of the firm.

Cartels can originate from a desire to reduce competition by competitors in the market; however, due to the illegal agreements from within, they cannot be enforced by contracts and must be based primarily on the trust of their members. The maintenance of institutions, even if corrupt, happens via enforcing and ensuring compliance with existing norms and beliefs while aiming at their expansion (Lawrence \& Suddaby, 2006). Yet these same cartels, which don't comply with norms, beliefs, and laws of most countries, might also engage in corrupt practices to win bids and tenders in megaprojects. These cartels might create and follow governance practices that rely on the trust of its members to be successful. Therefore, understanding how companies create durable corrupt institutions (cartel) is essential for the anti-corruption fight. This is also important since research on institutional work and anticorruption practices is limited (with the exception of papers such as Castro \& Ansari, 2017).

Petrobras's case-study analysis offers an account of these corrupt practices in megaprojects and how the corrupt cartel, despite being illegal, relied on the self-motivated and mobilized actors and created institutionalized corrupt practices of governance. By 
analyzing different kinds of "work" used for the maintenance, I show how institutional work can be used as a theoretical lens in project management to better understand the workings of temporal organizations. Finally, by better understanding how corrupt governance is structured in projects and how trust develops among partners, project managers can improve anticorruption measures in project governance, develop mechanisms that enhance ethical conduct, and reduce corruption in megaprojects.

\section{THEORETICAL FRAMEWORK}

Projects' governance is influenced by the institutional context in which firms are embedded (Muller et al., 2017; Soderlund \& Sydow, 2019), and institutional theory has been used in the project-level analysis to explain how (Henisz et al., 2012; Muller et al., 2017). Institutions are "stable, repetitive, enduring activities enacted by multiple organizational members without significant thought about the propriety, utility, or nature of behavior" (Greenwood et al., 2011). They are "social structures that have attained a high degree of resilience. [They] are composed of cultural-cognitive, normative, and regulative elements that, together with associated activities and resources, provide stability and meaning to social life" (Scott, 2005:48). In this respect, institutionalization is the process through which "social processes, obligations, or actualities come to take on a rule-like status in social thought and action” (Meyer \& Rowan, 1977: 341).

One way to try to understand how institutions are created, maintained, and disrupted is to look at the work of their actors (Phillips \& Lawrence, 2012; Lawrence, and Suddaby (2006) describe institutional work as "purposive action aimed at creating, maintaining and disrupting institutions" (p. 215). Institutional work arises from empirical research focusing on micro-level and macro-level practices, which offer categories and concepts used to "creatively navigate within their organizational fields" (Lawerence \& Suddaby, 2006, p. 219). Work focuses on the everyday life of actors within institutions and their role in influencing different institutions of 
which they are a part (Lawrence, Suddaby, \& Leca, 2009) and how practices and norms are institutionalized (Dorado, 2005; Tolbert \& Zucker, 1996). Several works of "purposive action" involved in maintaining institutions are found within this concept and are useful for the analysis of our case.

To maintain institutions, enforcing and ensuring compliance with existing norms and beliefs is necessary while aiming at their expansion (Lawrence \& Suddaby, 2006). Institutional maintenance explains how social structures are supported through more or less conscious action. The maintenance can be divided into two categories: rule-based work and norm-based work (Lawrence \& Suddaby, 2006). Rule-based work includes the creation of rules that enable work, policing, and coercive barriers aimed at deterring institutional change. Norm-based work includes actions such as valorizing and demonizing, by creating examples to demonstrate the norms of institutions, mythologizing and embedding daily routine activities of the participants. Lieftink et al. (2019) emphasize the need for "relational institutional work" among the partners within a particular industrial field for its success. Yet, they focus on the delivery model and do not consider its potential "dark side."

Construction of megaprojects will span across years and will face several challenges. Thus, organizations will coexist with conflicts, and maintenance work can be done to create more harmony and balance so projects can be delivered (Van Marrewijk, et al. 2016). Uriarte et al. (2019), also points out that projects and their environments need institutional legitimacy, helping actors to the successful delivery of projects. Tensions will be present at different times in the projects and several governance choices will be affected (Bakker, et al., 2016). For the project to be delivered, it will require and commitment from members and interpersonal trust and communication (Gorse \& Emmitt 2003).

Yet, the idea of "illegitimate" practices becoming accepted and normalized is a paradox in institutional theory because corrupt practices can become part of cognition (taken for 
granted), which violates the regulative and normative pillars of institutional theory (Scott, 2005). We still understand little about the maintenance of corrupt practices and the mechanisms that reinforce and maintain corrupt institutions over long periods. Furthermore, how project-management firms and individuals develop trust and create a governance mechanism in an illegal setting that maintains long-term corrupt relationships is still unclear.

\section{Corrupt Institutions}

Corrupt actors will co-opt, influence, and control processes across the field, while concealing such activities and demands to external members of the group. Corruption can also be analyzed at the field level, and mapping the field of study is important to understand the contours of the market competition. The mapping of corruption in the field should include the role of institutional rules, political processes, ownership structure, institutional structure, and other organizational forms that can lead to more embedded corruption. Therefore, understanding micro-level practices and macro-level corruption, and how they relate is very important Misangyi et al. (2008) for example, offer insights at the micro-level, how institutional entrepreneurs can change corrupt practices at the societal level by attempting to change society's perception of the symbolic rewards of these activities. Misangyi et al. talk about changes implemented by the World Bank and international organizations in former Yugoslavia to try to change corrupt practices. Gabbioneta et al. (2014), has both the field and societal level corruption.

Seo and Creed (2002) believe contradictions in the field lead to collective awareness and institutional change because they are based on unstable foundations. However, as we know, corruption and illegitimate activities can become institutionalized within organizations, projects, and also wider society. Illegal practices not accepted in society can be legitimized at a group or field level such as in a cartel. 


\section{Trust and Corruption}

Trust can be seen as a foundation for social order (Lewicki et al., 1998). Less discussed is the use of trust for corrupt activities that go beyond the socially accepted orders. Trust is particularly important when there are vulnerability and risk (Becker, 1996). However, trust among these members is not only a substitute for control (Rousseau et al., 1998). When a group of organizations tries to collaborate, trust, some kind of governance is necessary among members.

Illegal activities such as a cartel of construction companies involved in several megaprojects are extremely risky to all members (project network, clients and suppliers), therefore trust is even more important. So among collaborating project actors, opportunistic behavior should be limited and motivations for cooperation exist (Swärd, 2016). Trust and the limitation of opportunistic behavior should be particularly relevant in an illegal group activity to survive in time such as a cartel distributing projects among members. Therefore, understanding how corrupt cartels create governance practices to maintain the management of a series of megaprojects is essential.

\section{METHODS}

This study started with a broad empirical question regarding how firms sustain corruption for long periods. Specifically, I was interested in what work companies and actors were using in their projects to maintain long-term corrupt relationships, and how actors deploy them. I used several methods (Stigliani \& Ravasi, 2015) in my research process rather than a research recipe book when analyzing this unconventional dataset (Eisenhardt, Graebner, \& Sonenshein, 2016).

Combinations of different qualitative methodologies are gradually becoming more common (Stigliani \& Ravasi, 2015). The corpus of data, such as court data proceedings and legislative public commissions of inquiries, has traditionally been ignored by project- 
management scholars but has been used in other social sciences. Most countries offer litigation data accessible to scholars (e.g., the Siemens case ${ }^{1}$ ) and this rich group of data offers researchers a chance to peer at some hidden practices adopted by firms. These data also provide and solve part of one of the main conundrums of studying deviant practices - the validity of data when analyzing, because they are verified by several state officials and among several states (e.g., WTO, Interpol). Particularly, plea agreements display real managerial decisions adopted by firms even if illegal. These individual-level data of the plea agreement offer insight into top management team motives, rationalizations, and cognitions and why they adopted such strategies.

Such a wide variety of data helped me make sense of how the corruption process unfolded. My analysis therefore also involved a detailed analysis of the data, visual mapping of the critical events (as seen in Figure 1), and temporal bracketing (Langley, 1999). I analyzed and reconstructed several corrupt contracts, relationships, and relationship webs. My research ethos and initial units of analysis are shown below. From a broad understanding of what happened, I then went on to analyze once more the prosecution files. After the initial analysis of the testimonies, I analyzed the mechanism described by the executives.

\section{Insert Figure 1 about here}

Due to the huge amount of data provided by the investigation, I decided to focus on relevant and workable sets of data after initial filtering. To better answer the broad research question, I decided to focus on Petrobras's investigated business executives. I initially focused on Paulo Roberto Costa, Petrobras's former executive director, who was the first high-profile arrest and a prolific collaborator. Then, I expanded my investigation to the testimonies of the other Petrobras executives given to the parliamentary commission of inquiry. Later, I watched

\footnotetext{
${ }^{1}$ https://www.siemens.com/press/pool/de/events/2008-12-PK/DOJ1.pdf
} 
the video of the interrogations and read the plea agreement conducted by the prosecution team on Petrobras's key investigated executives. These plea agreements are not only questions/interviews regarding who paid bribes to executives but are also a broader data collection where investigated executives are required to provide concrete evidence concerning the bribes' operationalization.

\section{Data Sources}

The Lava Jato (Car Wash), the critical case analyzed (Yin, 2013), is an ongoing investigation into the payment of almost $\$ 4$ billion in bribes to Petrobras's executives and to politicians by a group of construction companies that were involved in Petrobras's megaprojects for more than 10 years (Table 1). The criminal investigation started in Brazil and has so far led to more than arrests and several plea agreements with executives, lobbyists, and politicians.

Insert Table 1 about here

Part of the challenge of studying corruption is the struggle to collect reliable data such as interviews. The "corrupt" respondents may lie because they do not want to provide evidence that could incriminate them. Aware of such limitations, during the data collection, I incorporated additional data sources from the Brazilian Prosecution and the US Department of Justice. I started by analyzing all the sessions of Petrobras's parliamentary inquiry in 2014. Such sessions were recorded and transcribed, and the transcripts were made publicly available on the website of the Brazilian congress. I decided to use such rich data because they are extremely detailed and have already been used in previous studies in management (Gephart, 1993). Gephardt uses public inquiries to make sense of disaster scenarios, and with such data, one can seek in-depth first-person accounts of events. As my research developed, I also used publicly available court proceedings (Gabbioneta et al., 2013). 
Note the court documents use legal vocabulary, yet they follow a rigorous methodological process. The collection of evidence has been structured and collected as foundational investigative blocks for the prosecution to build up a case against corrupt individuals and companies. In this sense, it is also research that has to be evidence-based, and prosecutors have to collect reliable data that show suspected illegal behavior. However, analyzing archival data from court proceedings also presents some challenges; therefore, I enriched the dataset with quantitative public financial sources. I compared testimonies, financial data, judicial condemnations, apprehended documents of the companies, and publicly available financial reports. The additional financial data were provided by the Brazilian construction sector, the Brazilian Central bank, and the Brazilian government.

From these plea agreements and the collection of files from the prosecution, I started to build a better understanding of the case and built a narrative and web of corruption relationships per executive. I then filtered the relevant actors and excluded irrelevant testimonies. Finally, for robustness, I double-checked these transcribed testimonies using the NVivo software.

\section{ANALYSIS}

\section{Petrobras}

Petrobras (Petróleo Brasileiro SA) is one of the largest oil and gas companies in the world and was founded in 1957. It has operations in areas such as exploration and production, refining, transportation, distribution, gas, biofuel, and so on. Its stock market capitalization had a big growth (Figure 2) in value since the pre-salt oil deposits were discovered in 2006, the world commodities boom. Petrobras is a large employer, and in 2014 had more than 100,000 employees.

Insert Figure 2 about here 
Petrobras governance. The Brazilian federal government owns a minority share (28.67\%); of the company. However, it has the majority of the voting rights $(50.26 \%)$, therefore, the government can appoint its board members. Managers are promoted internally, and employees are hired following a public admission exam similar to the Brazilian public-sector admission exam. The internal governance that emphasizes the promotion of internal staff has been essential for its growth and development but is also related to its downfall.

Its top board of directors is composed of 10 members, six of whom the government appoints directly. Appointments to the senior board of Petrobras are made by the political patrons with strong ties to the construction industry. Petrobras managers and their appointments are made politically. The appointment of these managers is extremely important due to their responsibilities inside Petrobras. For example, Costa was managing billions of dollars in project contracts, which led to losses in every project, due to corruption and technical flaws. He had worked more than 30 years in Petrobras before being promoted to senior management, but was aware of the "cost" and the trade-offs he would have to face to be promoted to the highest echelons:

I got in through (in Petrobras) a public competition in 1977, 2 February 1977. I worked at the company for 35 years. Until I got my first political appointment... I worked for 27 years in various PETROBRAS department, chalking up several positions in the company, and I never needed political support to progress in my career. It was because of my ability that I got the various positions I held in the company. Unfortunately, you can't get on to the Board of PETROBRAS without political support. (Roberto Costa, Director of Supply Petrobras, 2014)

More specifically, in 2004, Costa, with the support of Jose Janene, the leader of the PP party in the government coalition, was nominated to the executive board of Petrobras as the executive director of Supply. According to the federal prosecutors and the pleas, the political agents responsible for the nomination of Paulo Roberto Costa would receive a percentage (around 1\%) of the value of each contract signed by the directorate. From 2004 to 2011, PP gave political support to Costa. However, in 2011, the PP lost political influence and members 
of the new controlling party, PMDB, decided to keep Costa at his post and started receiving the percentage of the bribes. In 2014, Costa was arrested, and in 2015, he was sentenced to 12 years in prison and returned to the prosecution USD 23 million acquired via bribes.

Companies that did not agree with the rules of the club or did not pay directors were either denied the opportunity to participate in future tenders or experienced delayed payments and the opportunity to meet Costa to discuss their current projects. A manager of Petrobras also had "the power to complicate things," as stated by one of the CEO members of the cartel:

In reality, a director of PETROBRAS has great power to disrupt and very little power to help. So, our participation, and I believe this is true of most companies, is much more about preventing harm, than to reap any benefit. (Augusto Mendonca Neto, ex-CEO Setal, 2015)

Petrobras' projects tenders. In the end, in the 1990s, Petrobras changed its way of conducting public tenders for its projects in order to make contracting out to the international market quicker. The new bidding procedure for tenders was the invitation letter, which a limited number of participants received, and the process was directly controlled by the executive directors of Petrobras. Several changes happened; for example, in 2004, just 8\% (Globo, 2014) of around $\$ 5$ billion spent by Petrobras in tenders was done through this discretionary invitation. The following year, this figure rose to $60 \%$, and in 2009 , it stood at $76 \%$ of the investments of the company that year.

The executives of Petrobras had close contact with the construction-company cartel from the beginning of 2004 when a group of construction companies struck a deal with the Director of Supply, namely, Costa, and the only companies invited to tender were members of the cartel, called the "club."

Insert Table 2 about here 


\section{The Cartel - "The Club"}

The $c l u b$ was a cartel of construction companies working with Petrobras that was active from 2003 to 2012 and formed a central part of the investigation. The coalition was also confirmed by the documents collected by the federal police and prosecution. The cartel offers a rich setting for understanding the institutional work dedicated to maintaining the governance between several members across the years. The cartel had several ways to deal with the external threats, and internally had clear governance to enforce its agreements.

Governance of the cartel. These companies that engaged in corrupt deals couldn't enforce the corrupt agreements (i.e., how to pay bribes generated in each project or deliver the promised amount), so trust among members is essential for these agreements to last over time.

A document found by the federal police in 2014 was headed "Proposal to close the Bingo," which showed rules similar to the Brazilian football league, but the prizes were project contracts (Figure 4). This document offers insight into the allocation mechanism and rules of the cartel.

Insert Figure 4 about here

The cartel meetings included the analysis of tenders for projects, and a chronological list of projects was assigned so that some companies were written out, and then members could choose those that were their priority (Plea CEO Mendonça Neto). This ranking was also designed to keep an equilibrium of projects distributed among the "club," Therefore, the club created processes and evolving rules in this illegal field, and they were respected and followed over the years. The CEO of Setal, one of the construction companies involved in the scandal with other directors of Petrobras, said this kind of contract (by invitation only as mentioned above) strengthened the cartel, which would choose the "winner" and set a high price for the 
contract.

Maurício Godoy, the ex-president of Toyo Setal, mentioned that sometimes decisions were made by bingo, putting the name of the tender on a piece of paper. Ricardo Pessoa, CEO of UTC, would call meetings with representatives of companies and provide a list of new tenders of Petrobras and decide to whom they would be assigned.

Trust and socialization inside the cartel. The governance rules and commitment of the cartel (based on trust) were to be followed when new executives joined:

An internal meeting at Camargo Corrêa, in which Leonel brought me the existing ongoing contracts, the existing commitments, the consultancy contracts to support these kickback payments. And all this was presented to me. (Eduardo Leite, Executive, Camargo Correia, 2015)

The cartel started with 16 companies but later expanded to 23 , with seven occasional participants. A boundary work defined who joined and benefited from the cartel. According to the CEO of Toyo Setal, who signed a plea agreement, the initial members of the club were Odebrecht, UTC, Camargo Correa, Techinit, Andrade Gutierrez, Mendes Júnior, and Promom. From 2006 onwards, new companies joined and were invited, such as OAS, Skanska, Queiroz Galvão, Iesa, Engevix, GDK, and Galvão Engenharia. The cartel of construction companies gained strength by 2004 when they made a deal with Costa. Collaborator has mentioned some activities of collusion from 1998, but from 2004 (Figure 3), they had total power and would coordinate tenders among themselves.

Insert Figure 3 about here

The bonds between the members of the corrupt megaprojects included inviting an associate from the cartel to events with their families to discuss strategies, such as the replacement of board members. When new members joined the group, they were socialized and taught how to adapt to long-standing practices and keep their corrupt predecessors' commitments. Trust was reinforced internally and aided the creation of the cartel. This 
colluding and setting of boundaries was a process of institutionalization and boundary work, where rules were gradually defined to maintain such activities:

They were intended to protect each other, right, so there wasn't a trade war between these companies. And so the story began. There was never a day, never a conversation that went like this: "No, from today this is what has been established." No, these things go through an evolutionary process, and this process started way back when all companies were going through great difficulties, through a difficult period suffered by the industry at the time. (Augusto Mendonca Neto, ex-CEO Setal, 2015)

The complex setup of the oil and gas field, with its technical nature, megaproject norms,

and rituals, requires trust among agents. An example of this particularity of the field follows:

I mean, it's a very complex thing. An oil production platform costs more than 1 billion dollars. So, these things aren't simple... the construction of these projects, which, as I said, are extremely complex - we're always using the latest technology available worldwide - and this involves over a hundred people at PETROBRAS. I do not doubt that, within this relationship between PETROBRAS and its suppliers, there are many opportunities for corruption, especially because there are not only opportunities but also very close interactions. We are talking about contracts with an execution time of approximately 4 years. So the interaction between the people from the companies and the people from PETROBRAS is extremely close and for a long period. There is no doubt that there are many. (Augusto Mendonca Neto, ex-CEO Setal, 2015)

Members were socialized even outside the companies, and they frequently met at dinners.

Bonds were also created over these 10 years, and the expectation was that even after they left their current positions, they would find a new role in the corrupt field. However, in spite of these "friendships," the coercion factor was still present and was extremely important, as described here:

We were sitting down in Júlio's house... I had been invited to dinner there. (...) Pedro Barusco spoke of bribes, of how much he estimated, within his control, that Camargo owed, and that it looked like patronage, (...) And the second time, at the time at which Renato Duque was leaving the board, he came to me asking for a consulting firm to be hired that he had opened for the payment of kickbacks, at which time it was said to have the required payment. (Eduardo Leite, Executive, Camargo Correia, 2015)

But this socialization work had other functions: for the cartel to continue to work when a new member arrived or replaced another, he (they were exclusively male) was socialized and 
introduced to the organization's previously accepted commitments in order to start the initial trust bonding and shared identity. This kind of work is particularly important because megaprojects can take several years to complete. Thus, when members entered the network, certain conditions had to continue in order to maintain existing processes, many of the nonlegally binding social agreements between parts. However, cartel members also did policing work to ensure the arrangements in place would be respected. The CEO of Camargo, when he was promoted to his first executive board, was told that he should honor previous "agreements" made by his construction company with other members of the cartel as explained here:

I was notified by the director who preceded me. He told me there was already an existing process, that is to say, there was a payment commitment from the company within the supply board and service board. (Dalton Avancini, ex-CEO, Camargo Correia, 2015)

In other words, these informal words of mouth contracts were also maintained by the trust among the different actors in the field and that was essential for a long-lasting relationship to be maintained.

\section{Corruption in the Megaprojects of Petrobras}

Specific projects in the portfolio of megaprojects generated the corruption money. A document found by the federal police showed a meeting of the participants of the cartel in Sao Paulo on August 14, 2009, clearly stating several negotiated projects with their cost and pricing strategy (Figure 5).

Insert Figure 5 about here

Lots of these projects had a series of problems beyond corruption, as mentioned by the CEO Dalton Avancini:

Member of Parliament- You said you called attention to poor basic projects, which opened up loopholes. 
Dalton Avancini- They did open them up... That's what happens when you have a poor project, is not it? I mean, it then allows a series of negotiations to take place during the performance of the contract and requires so many (financial) additions (to the cost).

(Dalton Avancini, ex-Ceo Camargo Correia, 2015)

The clear governance rules seemed detrimental to the stability of the group. Due to the number of projects and their complexity, miscalculated projects were often included that in the affected the overall cost of the projects. These loss-making contracts and failures created huge internal tensions at the construction companies because the cartel had agreed to pay bribes when they incurred a loss on a project:

There may be situations where I did a budget in which I predicted that an undue amount would be paid based on my result, and this would be a damaging project. I mean, we had these kinds of cases. And even so, these agents no longer wanted to charge undue amounts on these contracts. That is to say, a case where $100 \%$ came out of the company. porAbsolutely not (...) What the project generated was not even able to pay what was required by these public officials. However, there were contracts in which I estimated this contract, estimated an amount in which I would pay undue values, and I achieved this result. That is to say, in this case, he was paid in full from the contract. So, there was no rule for this. (Dalton Avancini, ex-CEO, Camargo Correia, 2015)

Another document (Figure 6) shows some examples of the apprehended documents that demonstrate the level and depth of formalization of the governance rules. The subsection of the contracts of Comperj Refinery lists the prizes of the cartel's "game." Such practices extended to several other contracts. To maintain the equilibrium on a large number of contracts on which the group members were bidding, the cartel created a clear rulebook regarding the division of tenders as an enabling work. As mentioned in the testimony of one of the CEOs (Plea of Mendonça Neto, 2015), this accountability helped build trust, cohesion, and stability between members of the group and was successful for at least a decade.

Insert Figure 6 tabout here

Performance of key Cartel Members 
These companies experienced exceptionally short- and medium-term growth in this period, which was strongly correlated with the activities of the cartel. The growth continued even when the commodities market started to collapse and Petrobras share prices started to tumble due to government interference to control inflation. Below you can see the performance of seven of the 10 largest companies of the country (three specialize in residential projects). As seen in the graph, the performance was exceptional, particularly compared to the general growth of the economy, and other sectors and even competitors in the construction industry. These seven companies were all investigated in the Car Wash operation.

Insert Table 3 about here

Yet, ultimately, this strong performance of companies and the "club" was closely associated with its demise. However, such short-term gain ended when top executives were arrested, the reputational damage to companies was complete, and losses occurred, such as unemployment and abandoned projects. So these short-term gains via corruption payments to executives and companies led to their demise. In 2016, more than half of the seven companies left the top 10 list of the largest construction companies. Collectively, they have paid billions of dollars in fines and a couple has asked for protection through bankruptcy law.

\section{DISCUSSION}

The corrupt side of trust and governance has not been fully addressed in projectmanagement studies. Previous research has usually focused on issues such as the positive influence of trust in projects (e.g., de Oliveira \& Rabechini Jr., 2019) or the importance of coordination, collaboration, and control in projects (Whyte, 2019) while ignoring the darker side of trust and governance. With uncertainty at all levels, even a corrupt group needs to have some fixed rules based on agreed governance and trust to function across years. 
In this case study, the top players in the construction industry in Brazil, with their specialized engineering skills, agreed and drafted a rulebook with governance rules, from project to organization level. Furthermore, to maintain a corrupt field across a lengthy period, institutional work was done to repair and even prevent change. (Table 4).

Insert Table 4 about here

In the next subsections, I discuss in more detail the corrupt side of governance and trust in projects. Finally, I develop a model that shows how institutional work is used to reinforce illegitimate collaboration among firms.

\section{Governance}

In this case study, we can see that some mechanisms of governance can enhance unethical conduct and increased corruption in the megaprojects. The cartel analyzed created an internal governance system with written codes and agreed-upon rules that led to several instances of collaborative work. Without the traditional contractual arrangement and procurement routes that construction companies use to agree on collaborations, a corrupt governance mechanism was put in place.

The cartel had several governance rules to deal with the external environment, to replace its members, and internally had clear rules to enforce its agreements. Work was done to make sure that the founding myths, such as the one self-defense against external enemies were kept. When new members joined the field, they had to be socialized and taught how to adapt to long-standing practices and keep commitments of their corrupt predecessors who have left the organization or been removed by the management. So there were different kinds of institutional work, to make sure the governance was kept into place this is in line with previous research exploring tensions that arise when new actors enter projects embedded in the institutional field (Uriarte et al., 2019). 
Finally, the governance framework adopted by members change with time and was legitimized by all participants. We can see that even in this illegal setting, their governance practices where dynamic adapted according to need and practice (Brunet, 2019).

Trust

Corruption involves not only the exchange of material resources but also symbolic goods. Trust among members of a cartel seems to be the binding "glue" among them the members and different institutional work reinforced it. Given that loyalty and trust are key symbolic goods, the presence of such ingredients is likely to sustain corporate corruption. Because illegal contracts can't be enforced and seldom drafted, the cartel members do not seem to have used violence or coercion, members kept their agreements because they trusted they would be delivered.

Institutionalized cartel members will want to share the responsibilities and risks of their megaprojects. But although the project-based sector should seek organizational justice (Unterhitzenberger \& Bryde, 2019), the concept of justice has nuances, and "justice" can be interpreted ambiguously by cartel members. These members need to believe they are getting the "fair" share of cartel's profit and there is a need to foster collaboration between megaprojects network partners even when doing illegal activities and. Therefore, trust can also lead companies to develop weaker ethical practices and increase corruption in megaprojects teams and network partners.

\section{Process Model}

My process model focuses on the maintenance of corruption in a group with a focus on the dynamic processes and tensions that arise from corrupt relationships and how a cartel was successfully maintained over the years. Changes in the cartel are legitimized by members that have established the norms, rewards, and rules, and in turn, trust and reward the compliant 
behavior of new members. The model shows how different work increases and reinforces the corruption in the projects and among partners.

Insert Figure 7 about here

\section{Contribution to empirical research}

By offering a deep understanding of how such illegal governance could happen, I expect to provide some basis for future researchers and anticorruption practitioners who wish to analyze the disruption of corruption, and the tools required to do so. Policymakers and compliance professionals should think about how to tackle individual pieces of this corruption puzzle (in contracts, governance, etc.) beyond cosmetic announcements by public relations departments. Additionally, practitioners and scholars need to identify more proactive strategies for dealing with corruption.

Additionally, project scholars should be more creative in their use of widely available data, particularly reliable court proceedings. I offer pathways that enrich project scholars' empirical research, using widely available non-conventional data, from court proceedings and parliamentary commissions of inquiry. This kind of dataset was particularly relevant when studying corruption, which faces several challenges regarding data collection, although widely accepted as a very relevant topic. Access to such detailed information on the operators of a corrupt field, the corruptors, the corruptness, and the mediators are unprecedented. Executives revealed the process of paying bribes, what contracts were awarded to the firms, and what strategies they adopted to win the contracts and maintain the relationships over several years. Also, social influence was important, so I analyzed societal-level information such as the development of different industries during the study period. 


\section{CONCLUSION}

To better understand the corrupt side of governance and trust and megaprojects, I analyzed the governance structures and institutional arrangements of a cartel involved in several mega projects in Brazil. For this corrupt cartel to last, it was essential for the group to find different ways to enhance trust, governance rules and collaborations. Initially, the corrupt awarding of projects can lead to short-term financial gains via the awards of multi-billiondollar contracts, yet in the medium and long run, the strategy became self-defeating. The negative impact of corruption led ultimately to the loss of credibility, destruction of the company's public image, the collapse of its market value, and, in many cases, bankruptcy.

I find that for corruption in megaprojects to be durable, paradoxically, corrupt governance and trust are necessary among criminal companies. By understanding and explaining the behavior of managers in such firms, we can better understand the persistence of

problematic corrupt practices in megaprojects and how they are maintained. The findings of this paper will help scholars and project managers who are interested in understanding and developing better toolkits to fight corruption in megaprojects. 


\section{REFERENCES}

Bakker, R. M., DeFillippi, R. J., Schwab, A., \& Sydow, J. 2016. Temporary organizing: Promises, processes, problems. Organization Studies, 37(12), 1703-1719.

Bechky, B. A. 2006. Gaffers, gofers, and grips: Role-based coordination in temporary organizations. Organization Science, 17(1), 3-21.

Becker, L.C., 1996. Trust and noncognitive security about motives. Ethics 107 (1), 43-61.

Biesenthal, C., Clegg, S., Mahalingam, A., \& Sankaran, S. (2018). Applying institutional theories to managing megaprojects. International Journal of Project Management, 36(1), 43-54.

Brunet, M. 2019. Governance-as-practice for major public infrastructure projects: A case of multilevel project governing. International Journal of Project Management, 37(2), 283297.

Castro, A., \& Ansari, S. 2017. Contextual "readiness" for institutional work. A study of the fight against corruption in Brazil. Journal of Management Inquiry, 26(4), 351-365.

de Oliveira, G. F., \& Rabechini Jr, R. 2019. Stakeholder management influence on trust in a project: a quantitative study. International Journal of Project Management, 37(1), 131144.

Dorado, S. 2005. Institutional entrepreneurship, partaking and convening. Organization Studies, 26: 385- 414.

Dorée, A. G. 2004. Collusion in the Dutch construction industry: an industrial organization perspective. Building Research \& Information, 32(2), 146-156.

Eisenhardt, K. M., Graebner, M. E., \& Sonenshein, S. 2016. Grand challenges and inductive methods: Rigor without rigor mortis. Academy of Management Journal, 59(4), 1113-1123.

Gabbioneta C, Prakash R, Greenwood R. 2014. Sustained corporate corruption and processes of institutional ascription within professional networks. Journal of Professions and Organization, 1(1), 16-32.

Gabbioneta C, Greenwood R, Mazzola P, Minoja M. 2013. The influence of the institutional context on corporate illegality. Accounting, Organizations and Society, 38(6-7), 484-504.

Gephart. R. 1993. The textual approach: Risk and blame in disaster sensemaking. Academy of Management Journal. 36, 6, pp.1465-1514.

Giezen, M. 2012. Keeping it simple? A case study into the advantages and disadvantages of reducing complexity in mega project planning. International Journal of Project Management, 30(7), 781-790. 
Gorse, C. A., \& Emmitt, S. 2003. Investigating interpersonal communication during construction progress meetings: challenges and opportunities. Engineering, Construction and Architectural Management, 10(4), 234-244.

Greenwood, R., Raynard, M., Kodeih, F., Micelotta, E. R. \& Lounsbury, M. 2011. Institutional complexity and organizational responses. Academy of Management Annals, $5,317-371$.

Henisz, W. J., Levitt, R. E., \& Scott, W. R. 2012. Toward a unified theory of project governance: economic, sociological and psychological supports for relational contracting. Engineering Project Organization Journal, 2(1-2), 37-55.

Kivilä, J., Martinsuo, M., \& Vuorinen, L. 2017. Sustainable project management through project control in infrastructure projects. International Journal of Project Management, 35(6), 1167-1183.

Langley, A. 1999. Strategies for theorizing from process data. Academy of Management Review, 24(4), 691-710.

Phillips, N., \& Lawrence, T. B. 2012. The turn to work in organization and management theory: Some implications for strategic organization. Strategic Organization, 10(3), 223230.

Lawrence, T. B., Suddaby, R., \& Leca, B. 2009. Institutional work: Actors and agency in institutional studies of organizations (pp.1-27). Cambridge, UK: Cambridge University Press.

Lawrence, T. B., \& Suddaby, R. 2006. Institutional work. In S. Clegg, C. Hardy, T. Lawrence, \& W. Nord (Eds.), Handbook of organization studies (pp. 215-254). London, England: Sage.

Lewicki, R.J., McAllister, D.J., Bies, R.J., 1998. Trust and distrust: new relationships and realities. Acad. Manag. Rev. 23 (3), 438-458.

Lieftink, B., Smits, A., \& Lauche, K. 2019. Dual dynamics: Project-based institutional work and subfield differences in the Dutch construction industry. International Journal of Project Management, 37(2), 269-282.

Locatelli, G., Mariani, G., Sainati, T., \& Greco, M. 2017. Corruption in public projects and megaprojects: There is an elephant in the room!. International Journal of Project Management, 35(3), 252-268.

Meyer, J. W., \& Rowan, B. 1977. Institutional organizations: Formal structure as myth and ceremony. American Journal of Sociology, 80: 340-363.

Misangyi, V. F., Weaver, G. R., and H. Elms. 2008. 'Ending Corruption: The Interplay 
Among Institutional Logics, Resources, and Institutional Entrepreneurs.' Academy of Management Review, 33: 750-70.

Müller, R., Zhai, L., \& Wang, A. 2017. Governance and governmentality in projects: Profiles and relationships with success. International Journal of Project Management, 35(3), 378392.

Phillips, N., \& Lawrence, T. B. 2012. The turn to work in organization and management theory: Some implications for strategic organization. Strategic Organization, 10(3), 223230.

Rousseau, D.M., Sitkin, S.B., Burt, R.S., Camerer, C., 1998. Not so different after all: a crossdiscipline view on trust. Academy of Management Review 23 (3), 393-404.

Schembera, S., \& Scherer, A. G. 2017. Organizational strategies in the context of legitimacy loss: Radical versus gradual responses to disclosed corruption. Strategic Organization, 15(3), 301-337.

Scott, W. R. (2005). Institutional theory: Contributing to a theoretical research program. In K. G. Smith \& M. A. Hitt (Eds.), Great minds in management: 460-484. New York: Oxford University Press

Seo, M. G., \& Creed, W. D. 2002. Institutional contradictions, praxis, and institutional change: A dialectical perspective. Academy of Management Review, 27, 222-247.

Söderlund, J., \& Sydow, J. 2019. Projects and institutions: towards understanding their mutual constitution and dynamics. International Journal of Project Management 37(2), 259-268.

Stigliani, I., \& Ravasi, D. 2015. Combining qualitative methods to study collective cognition in organizations. Handbook of Qualitative Organizational Research: Innovative Pathways and Methods: pg444

Swärd, A. 2016. Trust, reciprocity, and actions: The development of trust in temporary interorganizational relations. Organization Studies, 37(12), 1841-1860.

Tolbert, P. S., \&Zucker, L. G. 1996. Institutionalization of institutional theory. In S. Clegg, C. Hardy, \&W. Nord (Eds.), The handbook of organization studies: 175- 190. Thousand Oaks, CA: Sage.

Unterhitzenberger, C., \& Bryde, D. J. 2019. Organizational justice, project performance, and the mediating effects of key success factors. Project Management Journal, 50(1), 57-70.

Uriarte, Y. T., DeFillippi, R., Riccaboni, M., \& Catoni, M. L. 2019. Projects, institutional logics and institutional work practices: The case of the Lucca Comics \& Games Festival. International Journal of Project Management, 37(2), 318-330. 
van den Ende, L., \& van Marrewijk, A. 2019. Teargas, taboo and transformation: A neoinstitutional study of community resistance and the struggle to legitimize subway projects in Amsterdam 1960-2018. International journal of project management, 37(2), 331-346. van Marrewijk, A., Ybema, S., Smits, K., Clegg, S., \& Pitsis, T. 2016. Clash of the titans: Temporal organizing and collaborative dynamics in the Panama Canal megaproject. Organization Studies, 37(12), 1745-1769.

Yin, R. K. 2013. Validity and generalization in future case study evaluations. Evaluation, 19(3), 321-332.

Whyte, J., 2019. How Digital Information Transforms Project Delivery Models. Project. Management. Journal 50 (2), 177-194 
TABLE 1

Data Sources

\begin{tabular}{|c|c|c|c|}
\hline & & Data Sources & Data Available \\
\hline \multirow{6}{*}{$\begin{array}{l}\text { Primary } \\
\text { Data } \\
\text { Analyzed }\end{array}$} & \multirow{3}{*}{$\begin{array}{l}\text { Parliamentar } \\
\mathrm{y} \\
\text { Commission } \\
\text { of Inquiry }\end{array}$} & \multirow{3}{*}{$\begin{array}{l}\text { http://www2.camara.leg.br/ativi } \\
\text { dade-legislativa/comissoes: } \\
\text {-comissoes- } \\
\text { temporarias/parlamentar-de- } \\
\text { inquerito } \\
\text {-55a-legislatura/cpi- } \\
\text { petrobras/documentos/notas- } \\
\text { taquigraficas/ }\end{array}$} & $\begin{array}{l}\text { More than } 120 \text { people } \\
\text { questioned }\end{array}$ \\
\hline & & & $\begin{array}{l}\text { More than } 230 \text { hours } \\
\text { of sessions }\end{array}$ \\
\hline & & & $\begin{array}{l}\text { More than } 6,000 \\
\text { pages transcribed } \\
58 \text { Sessions }\end{array}$ \\
\hline & \multirow{3}{*}{$\begin{array}{l}\text { Prosecution } \\
\text { files } \\
\text { Court } \\
\text { file(Plea } \\
\text { agreement } \\
\text { and } \\
\text { transcripts) }\end{array}$} & $\begin{array}{l}\text { http://www.mpf.mp.br/para-o- } \\
\text { cidadao/caso-lava-jato }\end{array}$ & $\begin{array}{l}50 \text { investigated } \\
\text { operators }\end{array}$ \\
\hline & & https://www.jfpr.jus.br/ & $\begin{array}{l}30 \text { hours of interviews } \\
\text { and videos }\end{array}$ \\
\hline & & $\begin{array}{l}\text { https://www.youtube.com/watch } \\
\text { ?v= } \\
\text { jzQQMPcOjPM }\end{array}$ & $\begin{array}{l}1,000 \text { pages or } \\
\text { investigation reports }\end{array}$ \\
\hline \multirow{2}{*}{$\begin{array}{l}\text { Additional } \\
\text { Data Cross- } \\
\text { Referencing }\end{array}$} & $\begin{array}{l}\text { Economic } \\
\text { Data }\end{array}$ & $\begin{array}{l}\text { https://seriesestatisticas.ibge.gov } \\
\text {.br/ }\end{array}$ & $\begin{array}{l}\text { Documents issued by } \\
\text { public authorities: } \\
\text { central bank, trade } \\
\text { associations, }\end{array}$ \\
\hline & $\begin{array}{l}\text { Financial } \\
\text { Data }\end{array}$ & $\begin{array}{l}\text { http://www.cbicdados.com.br/m } \\
\text { edia/anexos/070.pdf }\end{array}$ & $\begin{array}{l}\text { Construction Sector } \\
\text { Trade Body, } \\
\text { companies public } \\
\text { balances }\end{array}$ \\
\hline
\end{tabular}


TABLE 2

\section{Refineries Projects controlled by Costa}

\begin{tabular}{|l|l|l|l|}
\hline Projects & $\begin{array}{l}\text { Refinery of } \\
\text { Abreu e Lima }\end{array}$ & $\begin{array}{l}\text { Petrochemical } \\
\text { Complex of Rio- } \\
\text { Comperj }\end{array}$ & $\begin{array}{l}\text { Refinary Presidente } \\
\text { Getulio Vargas- Repar }\end{array}$ \\
\hline Value of tender (R\$) & 18 billion & 7.5 billion & 8.6 billion \\
\hline Main contractors & $\begin{array}{l}\text { Camargo } \\
\text { Correa, } \\
\text { Engevix }\end{array}$ & $\begin{array}{l}\text { Iesa, Queiroz Galvao, } \\
\text { Galvao Engenharia }\end{array}$ & $\begin{array}{l}\text { Mendes Junior, OAS, } \\
\text { Odebrecht, UTC }\end{array}$ \\
\hline $\begin{array}{l}\text { Estimated losses of } \\
\text { Petrobras (R\$) }\end{array}$ & 400 million & 249 million & N/A \\
\hline
\end{tabular}

Sources: modified from Brazilian Federal Prosecution Task force (2015) 
TABLE 3

Average annual growth of top construction companies versus other sectors of economy

\begin{tabular}{lcc}
\multicolumn{1}{c}{$\begin{array}{c}\text { Top Construction } \\
\text { Companies }\end{array}$} & $\begin{array}{c}\text { Average annual percentage } \\
\text { growth year in decade }\end{array}$ & $\begin{array}{c}\text { Public Sectors } \\
\text { Contracts Average } \\
\text { in the period }\end{array}$ \\
\hline \hline Andrade Gutierrez & 34.6 & 61 \\
Camargo Corrêa & 23.37 & 44 \\
Galvão & 51.2 & 67 \\
Mendes Junior Trading & 24.88 & 86 \\
Norberto Odebrecht & 23.692 & 56 \\
OAS & 27.72 & 78 \\
\hline Queiroz Galvão & 24.14 & \\
\hline Other Sectors of the & & \\
Industry & & 3.36 \\
\hline Industry & 5.9 & \\
Construction Sector & 3.06 & \\
\hline Agriculture & 4.06 & \\
\hline Services & & \\
\hline GDP & & \\
\hline
\end{tabular}

Source: Calculated by author from Brazilian Central Bank (2017) 


\section{TABLE 4}

\section{Examples of Institutional Work used for the governance of cartel}

\begin{tabular}{|l|l|}
\hline Work & When/how \\
\hline Socialization & Work to make sure there is a cohesion inside the cartel across the years \\
\hline Boundary & Expansion of membership of the club across the years \\
\hline Interaction & $\begin{array}{l}\text { Assigning contracts according to need, following the rule of a football } \\
\text { club }\end{array}$ \\
\hline Policing & $\begin{array}{l}\text { Making sure bribes where being paid in the due time and who would be } \\
\text { part of the club }\end{array}$ \\
\hline Deterring & $\begin{array}{l}\text { Limiting the participation of tenders in Petrobras to companies that } \\
\text { followed the rules of the cartel }\end{array}$ \\
\hline
\end{tabular}




\section{FIGURE 1}

Key Events during the Cartel's duration

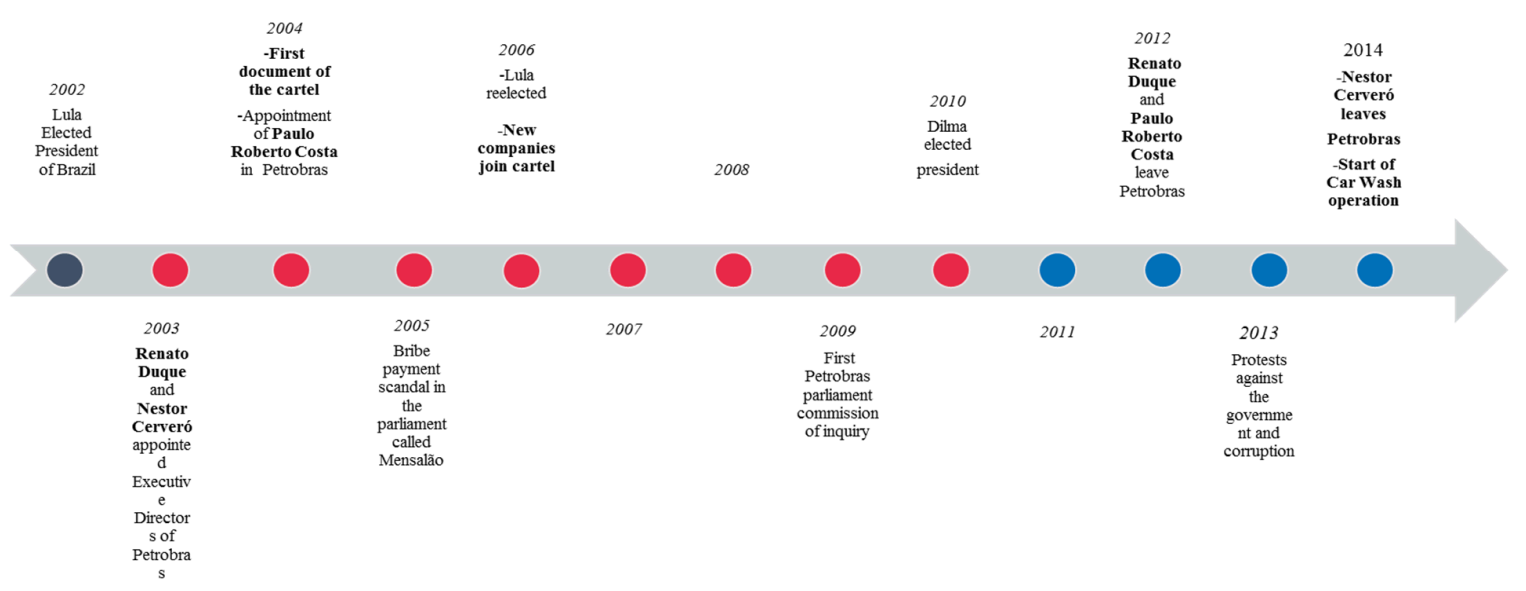


FIGURE 2

Petrobras Market Capitalization before the Carwash Investigation

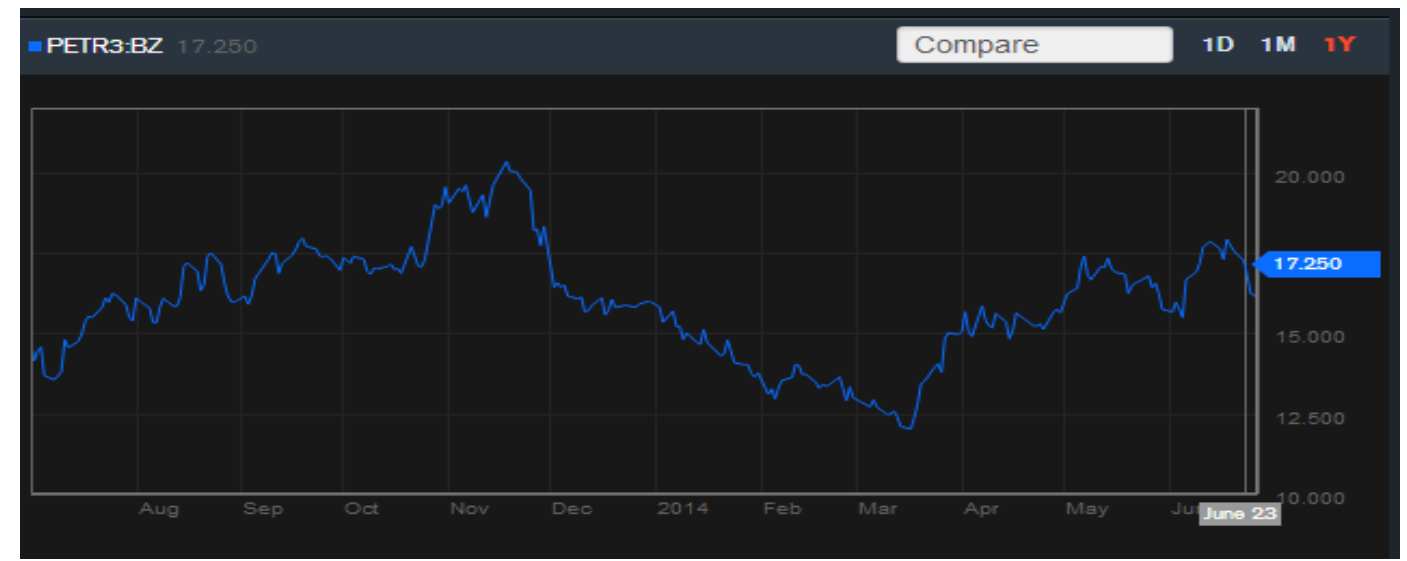

Source: Bloomberg (2014) 
FIGURE 3

\section{Chronology of cartel}

The 2000s

- Active involvement from 9 companies since 2004 when Petrobras executive, Costa, was appointed

- Growth to 16 companies

- Occasional participation of other companies and the negotiation of new members

- Other companies join the club "club"

- Contracts for RNEST refineries

- Contracts for Comperj refineries

The 2010s

- 2014-End of the club 
FIGURE 4

Cartel Rulebook- Includes the governance rules of the cartel and has been signed by all members.

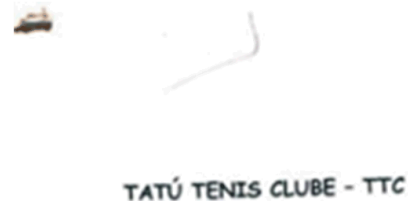

Criado $\mathrm{em} 11$ de fevereiro de 2004

1. O TTC concorda que o esporte nacional vem deterionando-se bostante $e$ que $\dot{E}$ fundomental trobalharem conjuntamente para preservar o tênis nocional e transforma-lo no melhor e mais rentável esporte nocional. Neste sentido as afuoçöes TTC devem procurar manter um mesmo estilo 1 tático, independente do jogodor titular, e os reservas devem prestar todo opoio necessório para a vitónia do $\mathrm{TTC}$ mediante que
tifulares.
Fica estabelecido que o TTC teró 5 (cinco) jogodores
- Guga
- Beker
- Koock
- Kirmyer
- Oncins

3. Os jogodores do TTC ocordam que iröo trabalhar unidos para que os próximos compeonatos, nos âmbitos nocional, estadual e municipal, sejam organizodos e dirigidos pelo TTC e que toda a renda dos jogos sejam revertidos para o TTC.

4. Os compeonatos já iniciodos năo terö̆o a participaçð̆o do TTC, a menos que, um de seus jagadores solicite o apoio do TTC e este tratard este jogo como excesălo.

5. Todos os jagodores ter ð̃o a mesma participoçăo nas rendas conquistodos pelo TTC, independentemente de serem tifulares ou nö̀ durante os jogos.

6. A coda nova definiçŏo da tabela do compeonato serdo revistos os jogos, os mandantes de campo e os participantes, com definiçăo de no mínimo 2 (dois) jogadores tifulares por jogo.

7. Coda jogador poderd́ indicar qual 0 jog० tem preferência de atuar. levando-se em conta sempre onde tem mais condiçöes de ajudar na vitório do TTC, devendo prevalecer a indicoşäo do(s) patrocinador(es).

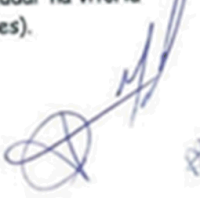

Source: Original Document Apprehended by Car Wash Operation 2015 
FIGURE 5

\section{Cartel's Agreed Prices of Projects and Profit Margin}

\begin{tabular}{|c|c|c|c|c|c|c|c|c|}
\hline CONTRATO & BID & $\begin{array}{l}\text { EMPRESAS } \\
\text { CONVIDADAS }\end{array}$ & $\begin{array}{c}\text { EMPRESAS } \\
\text { PROPONENTES E } \\
\text { PROPSTAS } \\
\text { APRESENTADAS }\end{array}$ & $\begin{array}{c}\text { A PROPOSTA } \\
\text { MENOR E X\% } \\
\text { OA } \\
\text { PROPOSTA } \\
\text { MAIOR }\end{array}$ & $\begin{array}{l}\text { VALOR DE } \\
\text { ESTIMATIVA }\end{array}$ & $\begin{array}{l}\text { UMMTE MÁXIMO } \\
\text { DE CONTRATACÁA } \\
\text { (VALOR DE } \\
\text { ESTIMATIVA + } \\
\text { 20\%5) }\end{array}$ & $\begin{array}{l}\text { VALOR DO } \\
\text { CONTRATO/ } \\
\text { VALR } \\
\text { CONTRATO EX\% } \\
\text { ACIMA DO } \\
\text { VALOR DE } \\
\text { ESTIMATIVA }\end{array}$ & $\begin{array}{c}\text { PERCENTA } \\
\text { GEM DA } \\
\text { PROPOSTA } \\
\text { VENCEDOR } \\
\text { A EM } \\
\text { RELAÇÃO } \\
\text { AO UMMTE } \\
\text { MAXIMO } \\
\text { DE } \\
\text { CONTRATA } \\
\text { ÇĀO }\end{array}$ \\
\hline \multirow{3}{*}{$\begin{array}{c}\text { REPAR - IERP } \\
1111 \text { (Contrato } \\
0800.0043363 .08 . \\
2)\end{array}$} & \multirow{3}{*}{$1^{\circ}$ BID } & \multirow{3}{*}{ 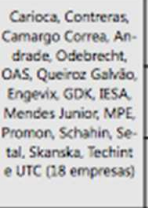 } & $\begin{array}{l}\text { 1. Consórcio INTERPAR } \\
\text { (MENDES/MPE/SETAL): } \\
\text { RS 2.253.710.536.05 }\end{array}$ & $\begin{array}{l}123 \\
87,31 \%\end{array}$ & \multirow{3}{*}{ RS 2.076.398.713,04 } & \multirow{3}{*}{ RS 2.491.678.455.65 } & $\begin{array}{c}\text { RS } \\
2252710536,05\end{array}$ & \multirow{3}{*}{$90,44 \%$} \\
\hline & & & $\begin{array}{c}2 \text { CONS6rCio } \\
\text { OOEBRECHT/OAS/UTC: } \\
\text { RS 2 2472.953014.05 }\end{array}$ & $\begin{array}{l}1.22 \\
91.13 \%\end{array}$ & & & \multirow{2}{*}{$8.49 \%$} & \\
\hline & & & $\begin{array}{l}\text { 3. Corsibecio } \\
\text { QUEROZOZRESA. RS } \\
\text { 2.581.2334220,41 }\end{array}$ & $\begin{array}{r}2.3 \\
95.80 \%\end{array}$ & & & & \\
\hline \multirow{3}{*}{$\begin{array}{c}\text { REPAR - TERP } \\
112 \text { (Eontroto } \\
0800.0043403 .08 \\
-02)\end{array}$} & \multirow{3}{*}{$1^{\circ} \mathrm{BIO}$} & \multirow{3}{*}{ 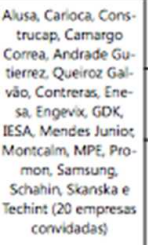 } & $\begin{array}{l}\text { 1. Consórcio CCPR - } \\
\text { REPAR: RS } \\
2.489 .772 .835 .01 \\
\end{array}$ & $\begin{array}{l}1.3 \\
91.89 \%\end{array}$ & \multirow{3}{*}{ RS 2093.988.284,45 } & \multirow{3}{*}{ RS 2.512.785.941.34 } & $\begin{array}{c}\text { RS } \\
2 \angle 88.315 .505,20\end{array}$ & \multirow{3}{*}{$99,08 \%$} \\
\hline & & & $\begin{array}{c}\text { 2. Consbecio IESA e } \\
\text { QUEEROZ GALVAO: RS } \\
\text { 2.681.312844,30 }\end{array}$ & $\begin{array}{c}1<2 \\
9285 \%\end{array}$ & & & & \\
\hline & & & $\begin{array}{l}\text { 3. Consbircio MNORADE e } \\
\text { TECHENT: RS } \\
2.709 .341 .946,33\end{array}$ & $\begin{array}{c}2 e^{3} \\
98,96 \%\end{array}$ & & & $18.83 \%$ & \\
\hline \multirow{5}{*}{$\begin{array}{l}\text { RNEST - } \\
\text { UHDT/NGH } \\
\text { edtal } \\
063431609-8\end{array}$} & \multirow{4}{*}{$\begin{array}{l}12 \\
\text { Bat }\end{array}$} & \multirow{4}{*}{$\begin{array}{l}\text { Camargo Correa An- } \\
\text { drade Gutierrez } \\
\text { Odebrecth OAS. } \\
\text { Queiroz Galvas, En. } \\
\text { gevix, IESA Mendes } \\
\text { Junior, MPE, Setal. } \\
\text { Skarska, Techint } \\
\text { UTC, GOK e Promon } \\
\text { (15 convidadas) }\end{array}$} & $\begin{array}{l}\text { 1. ConsDicio CONEST. } \\
\text { UHT-ODEBRECHT e OAS: } \\
\text { RS } 4.226 .197 .431 .48 \text {. } \\
\end{array}$ & $\begin{array}{l}1,4 \\
88,70 \%\end{array}$ & \multirow{4}{*}{ Rs 2.621 .843 .534 .67} & \multirow{4}{*}{ Rs $3.146212 .241,60$} & \multirow{4}{*}{ Prej. } & \multirow{4}{*}{ Prej } \\
\hline & & & $\begin{array}{l}2 \text { CAMARGO CORREA } \\
\text { RS } 4451.388145,30 .\end{array}$ & $\begin{array}{rl}1 & =2 \\
94 & 94 \%\end{array}$ & & & & \\
\hline & & & $\begin{array}{l}\text { 3. MENDES JUNDOR: RS } \\
4.583 .856912 .18\end{array}$ & $\begin{array}{l}2 \mathrm{e} 3 \\
97,11 \%\end{array}$ & & & & \\
\hline & & & 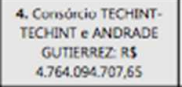 & $\begin{array}{l}3 \mathrm{e} 4 \\
96.21 \%\end{array}$ & & & & \\
\hline & 20 REAID & $\begin{array}{l}\text { Camargo Corres, An- } \\
\text { drade Gutierrez } \\
\text { Odebrecht OAS, } \\
\text { Queiroz Galvaa, En- } \\
\text { gevis, IESA Mendes } \\
\text { Junior, MPE, Setal. } \\
\text { Skanska, Techint } \\
\text { UTC, GDK e Promon } \\
\text { (15 convidadas) }\end{array}$ & 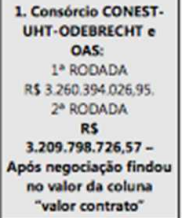 & $\begin{array}{c}1.4 \\
1 \cdot R O D A D A \\
81,14 \% \\
1 \in 3 \\
24 \text { RODADA } \\
84,89 \%\end{array}$ & RS 2.892.667.038.77 & RS 3.216200 .446 .52 & $\begin{array}{c}\text { RS } \\
3.190 .646503 .15\end{array}$ & $99,80 \%$ \\
\hline
\end{tabular}




\section{FIGURE 6}

\section{A Spreadsheet with the Distribution of Contracts Within one of the Megaprojects}

\section{(RNEST)}

\begin{tabular}{|c|c|c|c|c|c|c|c|c|c|c|c|c|c|c|c|c|c|}
\hline Jarenes & 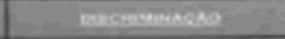 & \multicolumn{15}{|c|}{ 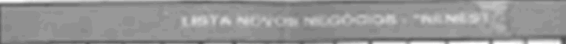 } & \multirow{2}{*}{ 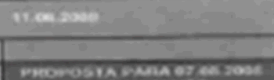 } \\
\hline \multirow{16}{*}{ erincers } & & mene & sa & var & $\mathrm{me}$ & met & Ae & es & कx. & wat & ea) & -2 & $\Delta$ & $\mathrm{kg}$ & Ivx & $\infty$ & \\
\hline & 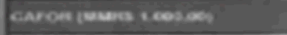 & & & & & & & & & & & & & & & & 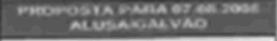 \\
\hline & 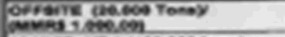 & & & & & & & 1 & & & 1 & & & & & & comprts ma nue \\
\hline & 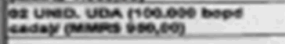 & & 1 & & & & & & & & & & 1 & & & & Comvire wa neun \\
\hline & 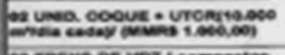 & & & & & & & 1 & & & 1 & & & & & & conevis ma nua \\
\hline & 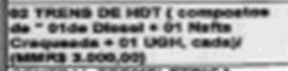 & & 1 & & & & & & & & & & 1 & & & & compre ma mesa \\
\hline & 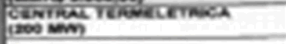 & & & & & & & & & & & & & & & & 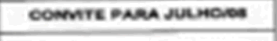 \\
\hline & 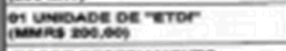 & & & 8 & & 8 & - & & & & & & & & 1 & & 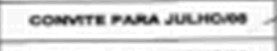 \\
\hline & 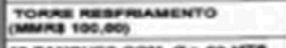 & & & & 1. & & & & & & & & & & & & 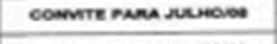 \\
\hline & 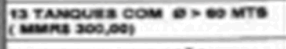 & & & & & & & & & & & 1 & & & & & COAMTE RARA JUENODA \\
\hline & 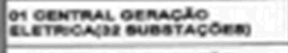 & & & & & & & & & & & & & & 1 & & comite Rara sulvoves \\
\hline & or esemtrul automagno & & & & & & & & & & & & & & & & 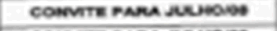 \\
\hline & erta & & & & & & & & & & & & & & & & 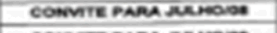 \\
\hline & 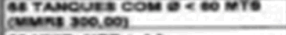 & & & & & & & & & & & 1 & & & & & 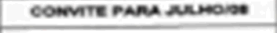 \\
\hline & 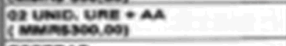 & 1 & & & & & & & 1. & 1 & 2 & & 1 & & & 1 & 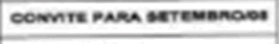 \\
\hline & $\begin{array}{l}\text { corenas } \\
\text { Guns aceas }\end{array}$ & & & & & & & & & & & & & & & & comnte mach saremanost \\
\hline & & & & & & & a & ल) & & $m=1$ & an & & 201 & & wat & ing & \\
\hline & & & & & & & & & & & & & & & & & \\
\hline & 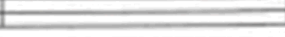 & & & & & & & & & & & & & & & & \\
\hline
\end{tabular}

Source: Original document apprehended by Car Wash operation 2015 
FIGURE 7

A Process Model of Institutional Work used to Maintain Cartel

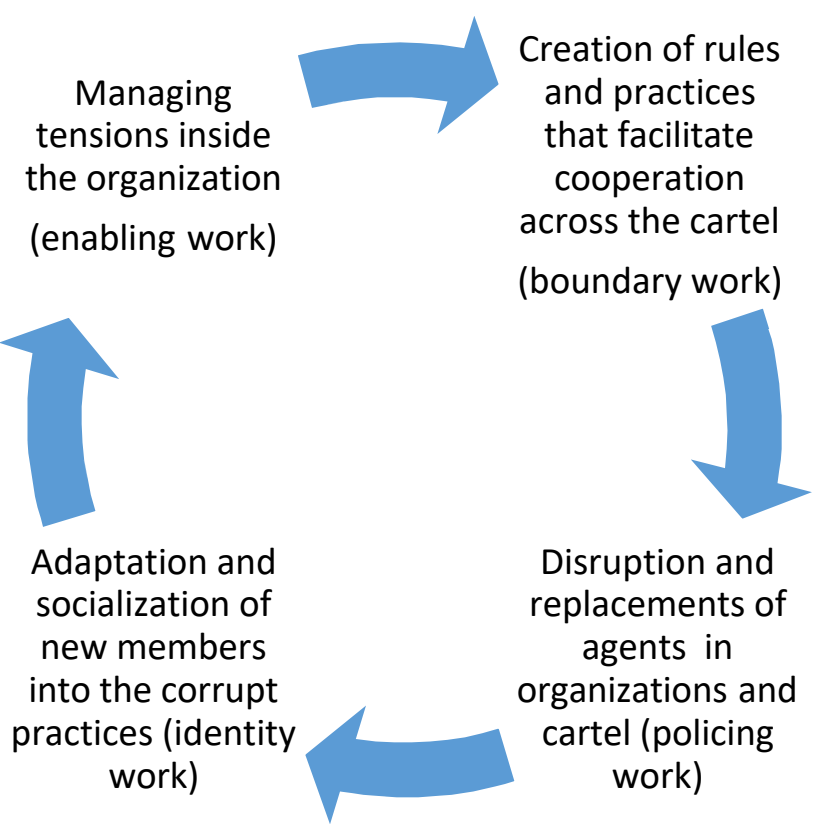

